УДК 32(477):316.422:316.3(045)

DOI https://doi.org/10.32837/pyuv.v0i5.924

\author{
Н. В. Пильгун \\ orcid.org/0000-0002-4539-5400 \\ кандидат юридичних наук, \\ доцент кафедри теорії та історії держави і права \\ Національного авіаційного університету \\ О.С. Слуцька \\ orcid.org/0000-0003-1677-1937 \\ студентка I курсу юридичного факультету \\ Національного авіаційного університету
}

\title{
ТЕОРЕТИКО-ПРАВОВИЙ АНАЛІЗ ПОЛІТИЧНОЇ СИСТЕМИ УКРАЇНИ
}

Політична система суспільства пов'язана 3 особливою сферою діяльності суб'єктів політики як системою взаємоузгоджених і взаємозумовлених дій держави, політичних партій, політичних громадських об'єднань, політичних рухів, спрямованих на реалізацію своїх інтересів у боротьбі за державну владу, ії утримання і використання. За всіх часів питання про політику розглядалося в єдності з питаннями про владу і державу. Політична система - це забезпечення інтеграції, розробка та реалізація загальної мети суспільства. Під політичною системою України розуміють сукупність політичних відносин, правових і політичних норм, інститутів та ідей, пов'язаних 3 формуванням і здійсненням влади та управлінням суспільством. Україна обрала демократичний тип політичної системи, в якій вона і функціонує.

На рівень та ефективність діяльності всієї політичної системи в Україні впливають взаємопов'язані, але відносно самостійні елементи самої правової системи. Право регулює поведінку людей у суспільстві і безпосередньо в політичній системі шляхом встановлення загальних, формально визначених зв'язків, які впливають на свідомість і волю суб'єктів політичної системи. Велике значення має правосвідомість суб'єктів політичної системи та безпосередньо політика щодо розвитку системи державотворення та реалізації політичних механізмів у суспільстві. Існують такі загальноприйняті функції права, як охоронна та регулятивна. Щодо останньої, то вона здійснюється завдяки усвідомленню особами обов'язковості правових норм і принципів, сприйняттю критеріїв правильності, соціальної виправданості поведінки суб'єктів політичної системи. Виходячи 3 цього твердження, можна зазначити, що всі суб'єкти політичної системи мають певний рівень політичної правосвідомості і потребують знань і розуміння як права, так і інших політико-правових явищ, що зумовлює залежність особи від суспільства. Політична система України нині перебуває на стадії розвитку всіх їі елементів структури, а також наповнення функцій новим змістом, що відповідає статусу незалежної самостійної держави. Становлення і розвиток державного устрою України відбуваються в період реформаційних процесів як сучасного суспільства, так і самої держави і всієї політичної системи. В політичній системі України прослідковуються позитивні новаційні зміни, які чітко виражаються в поступовій політичній структуризації суспільства, незавершеності процесів функціонування політичних партій, які своєю чергою прагнуть використовувати політичний досвід минулого з урахуванням змісту і специфіки політичного розвитку інших країн на сучасному етапі [1, с. 61$]$. Аналізуючи розвиток багатопартійності, можна передбачити, що партійна система в Україні поступово трансформуватиметься від атомізованої, 3 великою кількістю нечисленних, маловпливових партій, до більш стабільної системи поляризованого плюралізму з його класичним розділом на лівих, правих і центр. Зрештою, немає іншого інституту, крім політичних партій, який би успішніше справлявся 3 трьома найважливішими функціями - передачі влади, політичної мобілізації мас і легітимізації наявного режиму. Для визначення етапів такого переходу важливим напрямом дослідження виступають особливості становлення політичних інститутів у різних соціально-економічних умовах, функціонування державних систем в умовах глобалізації та регіоналізації. Важливим фактором впливу на розвиток політичних інститутів також є нормативний складник. Конституція України визначила засади формування і розвитку політичної системи, закріпила функції ïi окремих елементів, розкрила зміст та особливості діяльності держави у політичній системі [2, с. 616]. Сьогодні у державі відбувається процес становлення нової політичної системи, що проявляється у формуванні системи органів місцевого самоврядування, запровадженні інституту президентської влади, поділі державної влади та наявності механізму стримувань і противаг. 3 погляду 
особливостей загальносистемних якостей політична система України характеризується як:

- відносно стабільна (на поверхні) система, яка спроможна легко трансформуватися в нестабільну внаслідок поглиблення конфліктів між основними політичними блоками, у тому числі й усередині державного механізму;

- система з відносно низьким темпом соціальних процесів та недостатньо сприйнятлива до соціальних новацій;

- молода самостійна система, яка фактично не має достатньо ефективних сучасних традицій та досвіду самостійного функціонування;

- централізована, з деякими елементами регіоналізації та децентралізації;

- система, що здійснює не весь комплекс функцій, які є необхідними для забезпечення нормального функціонування цивілізованого суспільства;

- перехідна від закритої до відкритої;

- система, що діє в умовах надзвичайної, а не нормальної ситуації.

Основними напрямами формування і розвитку нової політичної системи України є:

- побудова демократичної, соціальної, правової держави;

- утвердження громадянського суспільства;

- подальший розвиток і вдосконалення політичних відносин, політичних принципів та норм;

- зростання політичної свідомості та політичної культури суспільства й особи;

- удосконалення діяльності засобів масової інформації [3].

3 огляду на вищенаведене можна стверджувати про те, що політична система України має всі характеристики, властиві їй як соціальному утворенню, для того, щоб якісно і ефективно функціонувати.

У процесі політичної трансформації та модернізації політичної системи необхідно шукати оптимальні шляхи для переходу від командно-авторитарної системи до раціональної з метою пом'якшення вірогідного зіткнення старих, традиційних для цієї політичної культури цінностей і норм політичного життя з новими модернізованими інститутами. При цьому виникає ряд проблем, пов'язаних з модернізацією, а саме: непідготовленість самої системи до реформування державного політичного режиму; заміна неефективних владно-політичних інститутів інститутами громадського суспільства; необхідність подолання кризи легітимності. Проте становлення інститутів громадянського суспільства відбувається складно, суперечливо, на тлі перманентних криз у політичній, економічній, соціальній i духовній сферах. Потрібно зауважити на тому, що не завжди вдається запровадити верховенство закону в усі сфери громадянського життя суспільства. Політична еліта, яка знаходиться у владі, часто буває не здатною вирішувати загальнодержавні проблеми. Засоби масової інформації виступають не стільки посередниками у відносинах між громадянським суспільством і державою, скільки використовуються для маніпулювання масовою свідомістю в інтересах їх власників і певних політичних сил $[4$, с. 5$]$.

Попри свій могутній людський, природний, економічний та науковий потенціал, Україна продовжує сповзати в глибоку системну кризу. Належним чином не проведені ні політичні, ні економічні, ні судові реформи, а суспільство політично не структуровано. Досвід України красномовно свідчить, що без розв'язання наріжних політичних проблем, без належної політичної організації суспільства будь-які економічні перетворення приречені на провал [5, с. 9]. Процес формування ринкової системи в Україні розпочався за відсутності зрілих ринкових структур, досвіду поведінки економічних суб'єктів у ринковому середовищі. Це спричинене деградацією державного управління економічними процесами, які у поєднанні з іншими аспектами діяльності держави призвели до гіперспаду, гіперінфляції. За роки незалежності Україна втратила майже половину промислового і сільськогосподарського потенціалу. В ідеологічній сфері посилюється криза духовності, невпевненість багатьох людей у своєму майбутньому, порушення конституційних прав людини і громадянина. Деструктивно впливають на духовну сферу міжконфесійні конфлікти, правовий нігілізм, злочинність, корупція, наростання ідеологічного авторитаризму, монополізація ЗМI, виникнення заборонених для критики зон, збідніння інформаційної сфери. У соціальній сфері не вдалося подолати поглиблення майнової нерівності, зупинити процес зубожіння переважної частини населення. Для соціально незахищених прошарків населення дедалі гострішою стає проблема фізичного виживання, знецінено чинники, які гарантують соціальну стабільність [6, с. 5].

Головними чинниками, що визначають першочергові кроки політичної реформи, є: розбалансованість наявної системи влади, домінування корпоративних інтересів та всеохопна корупція; необхідність докорінної зміни системи організації влади; необхідність впровадження нових моделей формування, організації діяльності, відповідальності органів державної влади та місцевого самоврядування, прозорості, підконтрольності та підзвітності перед суспільством; фінансова та економічна криза, що потребують термінової реалізації антикризових заходів 3 боку органів влади та місцевого самоврядування, спрямованих на забезпечення можливостей розвитку економіки, створення нових робочих місць, 
забезпечення належного рівня соціального захисту; формування чіткої практики політичної взаємодії владних гілок шляхом використання принципів компромісності та ідейної конкуренції, що дозволить сформувати виважену концепцію розвитку країни; підтримання практики громадянських обговорень за участю політичних діячів та авторитетних науковців, результативність яких формуватиме рекомендації щодо вирішення нагальних проблем, наявних у суспільстві [7]. Зокрема, можна виокремити ще такі фактори, які впливають на соціально-політичну нестабільність в Україні: політична еліта неспроможна вирішувати державні проблеми на рівні загальноцивілізованих правил і норм, втрата довіри народу до влади, наявність політичної перевтоми, соціальна нестабільність, допущення серйозних управлінських помилок, нездатність більшості із політичних лідерів до конструктивної управлінської діяльності, малоефективна і неузгоджена діяльність законодавчих і виконавчих владних структур, розрив економічних зв'язків 3 пострадянськими державами, посилення кризи духовності, поява міжконфесійних конфліктів, наявність правового нігілізму серед населення, високий рівень злочинності і корупції в державі, проблема реалізації демократичних основ в інформаційній сфері, наявність протистояння між місцевим самоврядуванням та органами виконавчої влади, недосконале формування механізму стримувань і противаг у діяльності органів державної влади, відсутність політичної рівноваги в суспільстві [8]. Виходячи з вищенаведеного, можна стверджувати про те, що діяльність політичної системи України здійснюється на основі правових і політичних норм, моральних цінностей, звичаїв і традицій. Вони визначають правила політичної поведінки і здійснюють вплив на суспільство. Правові норми закріплюються в законах і підзаконних актах: указах президента, постановах уряду, розпорядженнях, наказах міністерств, відомствах виконавчих органів.

Політичні норми закріплені в Конституції, законах, які регулюють політичні відносини, політичних документах держави і партій, міжнародних документах. Щодо конституційних принципів, то вони закріплюють основи державного і суспільного ладу і одночасно є основними цінностями країни. Наприклад, в економічній сфері це рівноправність приватної і іншої форм власності, створення умов, що забезпечують гідне життя і вільний розвиток людини; у соціальній - соціальне забезпечення; у духовній - ідеологічна багатогранність. А самі політичні рішення розповсюджуються через різні канали зв'язку, насамперед це засоби масової інформації (газети, радіо, телебачення), та доводяться до відома населення. Якщо вони недостатньо продумані чи не відповідають потребам і очікуванням громадян, то в суспільстві може виникнути реакція відторгнення, можуть посилитися дестабілізуючі процеси [9].

Ще одним елементом політичної системи України виступають громадські організації. Їх розрізняють багато видів: професійні спілки, жіночі, молодіжні, ветеранські, дитячі організації, наукові, технічні, культурно-просвітницькі, фізкультурно-спортивні та інші добровільні об’єднання громадян, творчі спілки, земляцтва, фонди, асоціації. Основні напрями їхньої діяльності: прийняття участі у громадському бюджеті, проведення безкоштовних заходів, реалізація власних проєктів для розвитку суспільних благ і громадських організацій. Основним ресурсом їхньої діяльності є люди, які готові плідно й ефективно працювати [11].

Процес глобальної інформатизації дедалі відчутніше впливає на життя людини, яка створює новітню історію України. Важливими проблемами сучасності, які потребують серйозного вивчення, є виклики інформаційної епохи й відповіді політико-культурного поля сучасного українського суспільства. Якщо ж проєктувати основні завдання політичної культури суспільства на пріоритети політичної науки в Україні в умовах інформаційної епохи, то їхня ієрархія з' явиться в наступному вигляді:

- дослідження процесу становлення в Україні політичної культури глобальної інформатизації і основних показників цього процесу, а також вивчення констеляції внутрішніх і зовнішніх його чинників;

- співвідношення низхідних (держава суспільство) і висхідних (суспільство - держава) зв'язків у формуванні типу особи і моделей політичної поведінки;

- констеляція традиції й інновації в розвитку політичної культури і політичної свідомості громадян, прогностичний аналіз ціннісних орієнтацій потенційних виборців і їхніх можливих переваг;

- зіставлення регіональних моделей рецепції сучасних політичних інститутів і моніторинг виникаючих проблемних ситуацій, зокрема віддзеркалення в масовій свідомості сучасних правових нормативів;

- вплив партійно-політичної системи на формування нової політичної культури інформаційної епохи [10].

Таким чином, визначення типу політичної культури в цьому політичному просторі допоможе з'єднати евристичні можливості структурно-функціонального аналізу, оскільки політична культура мотивує політику, мобілізує політичний потенціал сучасності, групує учасників сучасного політичного процесу. 
Тенденції розвитку політичної системи України акцентують свою увагу на збереженні соціальних стандартів, що були встановлені за часів авторитарного режиму. Швидкі зміни, що розпочинаються 3 реформування державно-політичної системи, зазвичай супроводжуються відставанням змін у суспільній свідомості, яка за умов впровадження демократичних інститутів відповідно впливає на весь законодавчий та державотворчий процес. Також особливо звертають увагу на взаємовідношення між гілками влади: законодавчої, виконавчої і судової. Метою функціонального поділу державної влади на законодавчу, виконавчу та судову $\epsilon$ розмежування повноважень між різними органами державної влади та недопущення привласнення повноти державної влади однією з гілок влади. Здійснення державної влади на засадах іiі поділу означає передусім самостійне виконання кожним органом державної влади своїх функцій і повноважень. Це не виключає взаємодії органів державної влади, в тому числі надання необхідної інформації, участь у підготовці або розгляді певного питання. Однак така взаємодія має здійснюватися на засадах законодавства [12].

Отже, політична система - це сукупність інститутів, які формують і розподіляють державну владу та здійснюють управління суспільством i його процесами, щоб втілити у життя інтереси певних соціальних груп. Політична система має монополію на владу в масштабі всього суспільства, визначає стратегію суспільного розвитку, забезпечує політичне й адміністративно-державне управління суспільними процесами, формує правову систему. Кожна система має свої певні переваги, а також застереження, а кожний тип політичної системи встановлюється в суспільстві відповідно до стану справ у ньому, особливостей його політичного розвитку, традицій та культури.

\section{Jimepamypa}

1. Щедрова Г.П., Барановський Ф.В. Основи політології : навчальний посібник. Видавництво СНУ Ім. В.Даля, 2011. 304 c.

2. Корельский В.М., Перевалов В.Д. Теорія держави і права : підручник для юрид. вузів. Видавництво Инфра-М. 2002. 616 c.

3. Політична система сучасної України. URL: http://politics.ellib.org.ua/pages-3343.html.

4. Скрипнюк О.В. Сучасна державна політика України: основні концептуальні підходи до визначення змісту поняття. Вісник Академії правових наук України. 2004. №4(39). 3 С. 4-6.

5. Журавський В.С. Політична система України: проблеми становлення і розвитку (правовий аспект). Київ : Парламент. 1999. 112 с .

6. Лазарєв В. Общая теория государства и права : учебник. Москва : Юристъ, 2001. 520 с.

7. Політична енциклопедія. Нац. акад. наук України інститут політичних $\mathrm{i}$ етнонаціональних досліджень імені І.Ф. Кураса. Київ : Парламентське видавництво. $298 \mathrm{c.}$
8. Андрій Матвійчик. Тенденції розвитку політичної системи сучасної України в контексті європейського досвіду. Курасівські читання - 2005. Наукові записки. № 30. С. 329-339. URL: https:// ipiend.gov.ua/wp-content/uploads/2018/07/ matviichyk tendentsii.pdf.

9. Політична система України та проблеми iㅣ реформування (трансформації) у контексті політично-правової реформи. URL: https://pidru4niki.com/ 12631113 /politologiya/politichna_sistema_ukrayini problemireformuvannya_transformatsiyi (дата звернення:06.12.2021)

10. Проскуріна О. Політична культура України: сучасні проблеми та досвід становлення в умовах глобалізації. Наукові записки. 2018. № 37. С. 142-151. URL: https://ipiend.gov.ua/wp-content/uploads/2018/ 07/proskurina_politychna.pdf

11. Громадські організації: як це працює. URL: https://www.prostir.ua/?blogs=hromadski-orhani zatsiji-yak-tse-pratsyuje-chomu-ya-obrav-ho-tsentrrozvytku-mista (дата звернення: 06.12.2021).

12. Конституція України:офіційний текст. Київ, 2020. URL: https://zakon.rada.gov.ua/laws/show/254 $\%$ D0 $\%$ BA $/ 96 \%$ D0 $\%$ B2 $\%$ D1 $\%$ 80\#Text.

\section{Анотація}

Пильгун Н. В., Слуцька О. С. Теоретико-правовий аналіз політичної системи України. - Стаття.

У статті проведено теоретико-правовий аналіз політичної системи України. Запропоновано визначення, що загалом політична система - це забезпечення інтеграції, розробка та реалізація загальної мети суспільства. Під політичною системою України розуміють сукупність політичних відносин, правових і політичних норм, інститутів та ідей, пов'язаних з формуванням і здійсненням влади та управлінням суспільством.

Велике значення для формування всієї політичної системи має правосвідомість суб'єктів та безпосередній рівень політики у сучасному суспільстві. На систему політики впливають правові основи, які здійснюються завдяки усвідомленню особами обов'язковості правових норм і принципів, сприйняття критеріїв правильності, соціальної виправданості та вплив самої поведінки суб'єктів політичної системи на всю систему державотворення.

В основі політичної системи виникає ряд проблем, пов'язаних з модернізацією всього суспільства, а саме: непідготовленість самої системи до реформування державного політичного режиму; заміна неефективних владно-політичних інститутів інститутами громадського суспільства; необхідність подолання кризи легітимності.

На цей час тенденції розвитку політичної системи зосереджують свою увагу на збереженні соціальних стандартів, а реформування державно-правової системи супроводжується відсталістю змін, які відбуваються у свідомості громадян, що, відповідно, впливає на державотворення і законодавчий процес. Політична система здійснює монопольний вплив на владу у масштабах всього суспільства, що своєю чергою є визначальним для розвитку сфер суспільства, формування правосвідомості і правової системи, створення структур управління над суспільними процесами. Перш за все політика мотивує до здійснення реформ і покращення суспільного життя.

Ключові слова: політика, політична система України, політична реформа, політичні норми, громадянське суспільство. 


\section{Summary}

Pilgun N. V., Slutska O.S. Theoretical and legal of the political system of Ukraine. - Article.

The article presents a theoretical and legal analysis of the political system of Ukraine. It is proposed to define that in general the political system is to ensure integration, development and implementation of the common goal of society. The political system of Ukraine is understood as a set of political relations, legal and political norms, institutions and ideas related to the formation and exercise of power and governance.

The legal awareness of the subjects and the direct level of politics in modern society are of great importance for the formation of the entire political system. The political system is influenced by the legal framework, which is carried out through awareness of the binding nature of legal norms and principles, perception of the criteria of correctness, social justification and the impact of the behavior of political actors on the entire state system.
At the heart of the political system are a number of problems related to the modernization of society as a whole, namely the readiness of the system to reform the state political regime, the change of inefficient political institutions by civil society institutions, the need to overcome the crisis of legitimacy.

At present, trends in the political system focus on maintaining social standards, and reforming the state and legal system is accompanied by backwardness of changes in the minds of citizens, which in turn affects the state and legislative process. The political system has a monopoly influence on power throughout society, which in turn is crucial for the development of society, the formation of legal awareness and the legal system, the creation of management structures over social processes. First of all, politics motivates to implement reforms and improve public life.

Key words: politics, political system of Ukraine, political reform, political norms, civil society. 